Georgetown University Law Center

Scholarship @ GEORGETOWN LAW

1993

\title{
Drawing a Line Between Killing and Letting Die: The Law, and Law Reform, on Medically Assisted Dying
}

Lawrence O. Gostin

Georgetown University Law Center, gostin@law.georgetown.edu

This paper can be downloaded free of charge from:

https://scholarship.law.georgetown.edu/facpub/757

21 J.L. Med. \& Ethics 94-101 (1993)

This open-access article is brought to you by the Georgetown Law Library. Posted with permission of the author. Follow this and additional works at: https://scholarship.law.georgetown.edu/facpub

Part of the Constitutional Law Commons, Health Law and Policy Commons, and the Health Policy Commons 


\section{Drawing a Line Between Killing and Letting Die: The Law, and Law Reform, on Medically Assisted Dying}

\section{Lawrence O. Gostin}

$\mathrm{T}$ raditional medical ethics and law draw a sharp distinction between allowing a patient to die and helping her die. Withholding or withdrawing life sustaining treatment, such as by abating technological nutrition, hydration or respiration, will cause death as surely as a lethal injection. The former, however, is a constitutional right for a competent or once-competent patient, ${ }^{1}$ while the latter poses a risk of serious criminal or civil liability ${ }^{2}$ for the physician, even if the patient requests it.

The confusion engendered by the line drawn by ethicists and lawyers between killing and letting die is illustrated by a series of cases. Dr. Jack Kevorkian, a retired pathologist, has used a "suicide machine" on several patients he barely knew. ${ }^{3}$ The suicide machine is constructed to allow the patient to perform the final act leading to death. Dr. Kevorkian has continued to use his suicide machine despite an injunction issued by a Michigan court ${ }^{4}$ and the revocation of his medical license in Michigan in $1991^{5}$ and in California in $1993 .^{6}$

Dr. Timothy Quill wrote a sensitive account of his decision to prescribe barbiturates to a patient and to instruct her on how many tablets to take to end her life. ${ }^{7}$ The case differed from those of Dr. Kevorkian in that a longstanding physician/patient relationship existed and Dr. Quill had encouraged his patient to continue therapy for her terminal condition. "I wonder why," Dr. Quill wrote, "Diane who gave so much to so many of us had to be alone for that last hour of her life."

Additional accounts of physicians who knowingly hastened death have appeared in the literature. In an anonymous account published in JAMA ("It's Over, Debbie"), a physician claimed to have injected morphine sulfate sedative into a patient who appeared to be in pain, thereby causing her death. ${ }^{8}$ In another instance, Dr. Ronald Cranford wrote about his difficult decision to use an increasing dose of morphine on a patient knowing it would seriously depress her respiration. His intent was not to kill, but he knew it might speed her death. She died following one of the injections. ${ }^{9}$

In each of these cases death resulted, in one degree or another, from the physician's actions. Yet none of these physicians was convicted for assisting the patient's death. Three first degree murder charges were dismissed against Dr. Kevorkian; ${ }^{10}$ a grand jury refused to indict Dr. Quill,;1 authorities sought to uncover the identity of the author of "It's Over, Debbie," but no prosecution resulted; law enforcement agencies showed no interest in prosecuting Dr. Cranford.

The general public appears to look more favorably upon physician assisted dying than do the medical or legal professions. Referenda in the states of Washington ${ }^{12}$ and California ${ }^{13}$ were narrowly defeated. The Initiatives would have made these states the first jurisdictions in the Western Hemisphere to legalize medical aid in dying. (The practice of euthanasia in the Netherlands is not endorsed by statute, but is tolerated under specified circumstances under a ruling by the Dutch Supreme Court). ${ }^{14}$ In a Harvard School of Public Health/Boston Globe opinion poll, 64 percent of those interviewed favored physician assisted suicide by terminally ill patients who request it. ${ }^{15}$ Around the same time, a practical guide on how to 
commit suicide, Final Exit, reached the top of the New York Times Best Seller List. ${ }^{16}$

While much has been written about the professional ethics of physician assisted dying, ${ }^{17}$ little is known about where the law draws the line, whether the law is enforced in practice, and how the law should be reformed to reflect changing public opinion and ethical thought. This article addresses these questions and the need for clearer public policy on physician assisted dying.

\section{Distinguishing killing from letting die}

A substantial body of court decisions ${ }^{18}$ and scholarly publications ${ }^{19}$ has established that the risk of criminal liability for withdrawing or withholding treatment in accordance with the wishes of a patient or her surrogate is vanishingly small. The abatement of treatment is not an affirmative act, but rather a failure to provide further treatment. There is no criminal liability for failure to act unless there is a legal duty to act. The physician certainly has a duty toward her patients and ordinarily must use professional skill to promote the patient's health and save life. No duty to provide treatment arises, however, where a patient or her surrogate requests abatement of treatment.

The courts are still developing the exact parameters of the right to have treatment withheld or withdrawn. ${ }^{20}$ Certainly, a clear expression by a currently competent adult to abate treatment must be respected by the physician. ${ }^{21}$ Elizabeth Bouvia, for example, could require removal of a nasogastric tube, pursuant to ber belief that the burdens of artificial feeding outweighed the benefits of continued life with quadriplegia. ${ }^{22}$ Modern courts have tended also to respect the wishes of patients to refuse a blood transfusion pursuant to their religious beliefs. ${ }^{23}$ The decision to abate treatment belongs to the currently competent patient, not her physician, relatives or the courts. Nor must a competent patient be comatose or terminally ill to refuse treatment. ${ }^{24}$

Courts have extended this nearly absolute right of self-determination to incompetent patients whenever there is clear evidence that the patient, while competent, would have declined treatment. ${ }^{25}$ Courts, however, understandably look searchingly at the patient's medical condition or prognosis before sanctioning surrogate decisions for incompetent patients who have not expressed a clear position for abating treatment. The physician certainly has no duty to treat when the surrogate makes a request on behalf of a patient who is terminally ill $^{26}$ or in a persistent vegetative state. ${ }^{27}$ Nor have modern courts required judicial approval for these decisions to abate treatment. ${ }^{28}$ The physician's legal responsibilities are much less certain when the patient has a chronic disease with a low quality of life, such as dementia. A physician would be unwise to abate life sustaining treatment in such a case unless that decision has been previously sanctioned by a state court.

The physician, therefore, has no duty to treat a patient against her expressed wishes or best interests. Indeed, the physician may have an affirmative duty not to treat in these circumstances. Failure to follow the current or advance directives of a patient is more likely to result in liability than a decision to abate treatment. ${ }^{29}$

Barber v. Superior Court ${ }^{30}$ is the only case in which a physician was convicted for abating treatment in accordance with the request of the patient or her surrogate, and that conviction was overturned by the California Court of Appeal. The Barber court held that the omission to continue life support, although intentional and with the knowledge that the patient would die, was not an unlawful failure to perform a legal duty where the patient was "deeply comatose" and the decision was in accordance with the wishes of the family. Many courts reason that abatement of life sustaining treatment does not constitute suicide, because death occurs not at the hand of the physician, but due to the underlying disease. ${ }^{31}$

While a physician may "let a patient die" in accordance with the patient's expressed wishes or best interests, she cannot take active steps to end life. The Bouvia court said that "it is a crime to aid in suicide," or to engage in "assertive, proximate, and direct conduct such as furnishing a gun, poison, knife, or other usable instrumentality or means by which another could physically and immediately inflict some death producing injury upon himself." Other courts have emphatically rejected "active euthanasia" 32 or "mercy killing." 33

The determination of what is criminal and what is lawful is not understood by examining the physician's motives. The fact that a physician is motivated by the desire to end unendurable pain and suffering is irrelevant to criminal liability. ${ }^{34}$ The critical element is intent or knowledge. Did the physician intend to kill or know that death would result? Thus, a physician who injects or prescribes a sedative with the primary intent of reducing suffering would be acting lawfully even if she were aware of the depression of respiration. If the physician intended or knew the medication would depress respiration sufficient to cause death, criminal liability could ensue. This is no easy distinction to make in practice, but the law appears to rely on it.

\section{Legal prohibitions against physician assisted dying}

English common law punished suicide and attempted suicide with forfeiture of the person's property and ignominious burial..$^{35}$ Punishment, however, was reduced if the motive was "weariness of life or impatience of pain," and no penalty ensued if the person was insane. ${ }^{36}$ The law has recognized a person's pain and suffering since the time of Blackstone, ${ }^{37}$ although suicide was not completely excused even for the "hopelessly diseased." 38 
During the colonial period, the United States clearly opposed suicide. However, by the 19th century suicide was no longer considered a criminal offense. Currently, with one possible exception, ${ }^{39}$ no state in the United States punishes suicide or attempted suicide. ${ }^{40}$ Yet, prohibitions against assisting a person to commit or attempt suicide can be found in the criminal law. While it may appear illogical to punish a physician for assisting a patient to do something that is legal, the reasoning is that it is practically impossible to impose a sanction on the patient; the law also seeks to protect patients against undue influence to consent to medically aided dying.

The physician risks criminal liability when she: (1) directly causes the patient's death, for example, by administering a lethal dose of medication; (2) induces the patient to take her own life by force, duress, or deception; or (3) assists the patient to take her own life by providing medical advice or providing the means. The modern law is on a surer footing when dealing with, causing or inducing suicide than when assisting it.

\section{Directly causing the patient's death}

A physician who directly takes the life of a patient commits a criminal offense even if the patient desires to die. A physician would be regarded as the agent of a patient's death if she administered medication or other medical procedures with the intent or knowledge that the patient would die. Thus, the administration of a lethal injection is a crime irrespective of the patient's wishes, quality of life or prognosis. Non-physicians have been convicted of criminal homicide for injections of a fatal dose of licit or illicit drugs at the request of the person. ${ }^{41}$ A physician's license to practice medicine would not excuse her from liability in such circumstances.

A physician who actively participates in the act of causing death, such as by placing the lethal dose of medication in the patient's hand or mouth ${ }^{42}$ risks prosecution for murder or manslaughter. ${ }^{43}$ The physician would not be considered to be assisting suicide under a state statute providing for a lesser offense. ${ }^{44}$ Most statutes prohibiting assisted suicide do not contemplate active participation in an overt act directly causing death, but only some participation in the events leading up to the commission of the suicide, such as furnishing the means..$^{45}$

A modern day example is provided in People $v$. Cleaves. ${ }^{46}$ Cleaves was living with and helping a friend who was in an advanced stage of AIDS. He met another person with AIDS and, after a lengthy discussion, that person resolved to commit suicide. The person with AIDS tied a sash around his neck, asked Cleaves to tie his hands and feet with the sash from his neck, and proceeded to strangle himself. The California Court of Appeal held that if the defendant actually participates in the death of the suicide victim, he is guilty of murder. Neither the consent of the victim nor the absence of malice reduced the crime of murder.

\section{Inducing a patient to commit suicide}

A physician may also be convicted of criminal homicide for inducing a patient to kill herself by force, duress, or deception. ${ }^{47}$ Such purposeful action to cause a person's death would be viewed as homicide in all jurisdictions. ${ }^{48}$ Strong persuasion of a person to commit suicide, while not amounting to force or duress, may be viewed as undue influence. A physician is in a position to exercise authority over the patient and must exercise restraint in directly influencing the patient's decision to take her own life. ${ }^{49}$

The theoretical underpinning for convicting a physician for causing or inducing a person's suicide is that consent is not a defense to most criminal offenses: "Murder is no less murder because homicide is committed at the desire of the victim."s0 The interest protected by the criminal law is considered public, not private. $^{s 1}$ The patient's consent or submission to the physician's lethal procedure is, therefore, immaterial.

\section{Assisting suicide}

While causing or inducing suicide is uniformly considered a crime, no national consensus exists about assisting suicide by providing medical advice (e.g., discussion about effective or painless ways to commit suicide) or by providing the means (e.g., writing a prescription). The law is relatively clear in those 26 states that have enacted specific statutes prohibiting assisted suicide. ${ }^{52}$ Michigan enacted a statute in February, 1993 that made assisted suicide a felony punishable by up to four years imprisonment and a $\$ 2,000$ fine. ${ }^{53}$ The statute was held unconstitutional in May, 1993 by Judge Cynthia Stevens of the Wayne County Court. Judge Stevens found that the statute was enacted without public hearings. The Michigan Attorney General has filed an appeal against Judge Stevens' decision. ${ }^{54}$ Statutes in two other states prohibit causing suicide, but not assisting it. 55 Two additional states appear to retain assisted suicide as a common law offense. ${ }^{56}$ A person who assists another to die in a state that specifically recognizes the crime is unlikely to be charged with a more serious offense such as murder or solicitation to murder. ${ }^{57}$

The states that specifically prohibit assisted suicide either classify it as a unique offense (e.g., CA, NY) or define it as a type of murder or manslaughter (e.g., AZ, $\mathrm{OR}, \mathrm{HI}$ ). Assisted suicide statutes in several states are part of, or coexist with, natural death acts (e.g., KS, WA, WI). The Model Penal Code (sec. 210.5) establishes aiding or soliciting suicide as an independent offense: "A person who purposely aids or assists another to commit suicide is guilty of a felony of the second degree if his conduct 
causes such suicide or an attempted suicide, and otherwise of a misdemeanor." Attempted suicide statutes prohibit "intentional" or "purposeful" acts of assistance. While some statutes merely prohibit wilfully "assisting" or "abetting," many statutes also prohibit "advising" or "encouraging."

Difficulties arise in states that have no statutory or common law offense of assisted suicide. Several courts in the late 18th and early 19th centuries held an individual who assists in a suicide as a principal to murder. ${ }^{58}$ In People v. Roberts, for example, a husband was convicted of murder for assisting his wife to commit suicide. His wife had multiple sclerosis and, at her request, he placed a poisonous drink within her reach..$^{99}$

It is exceedingly rare for a modern court to convict a person of murder for assisting a suicide. A few modern courts, in extreme cases involving violent deaths, have found individuals guilty of the lesser offense of negligent homicide ${ }^{60}$ or voluntary ${ }^{61}$ or involuntary manslaughter. ${ }^{62}$ In a few states, aiding or soliciting suicide has been held to be no crime at all on the ground that suicide itself is not unlawful.63

\section{Publication of a suicide guide}

It is highly unlikely that the author of a suicide manual could be convicted of the offense of assisted suicide in the absence of any specific intent to kill an identifiable person. A court in England refused to issue a declaration to limit the distribution of the book published by EXIT, The Guide to Self Deliverance. The court said that distribution of the book could be a criminal offense only if the defendant gave the book to a person intending to assist the person to use the contents of the book to take his own life. ${ }^{64}$ The general secretary of EXIT was convicted and sentenced in another case for conspiracy for aiding and abetting another's suicide through publication and distribution of the guide. The Court of Appeal upheld the conviction, not because of the publication, but because he put the person "in touch" with an individual who he knew would assist in the act of suicide. ${ }^{65}$

No such prosecution has occurred in the United States despite the publication of Derek Humphry's Final Exit and reports that the book was used by people taking their own lives. Mere publication would not produce liability. By analogy, a rock musician and others were acquitted of aiding, advising or encouraging suicide for recording and disseminating music which a teenager listened to before killing himself. ${ }^{66}$

\section{Theory versus practice:}

The absence of risk of criminal liability

Whether or not a state has an assisted suicide statute, it will be difficult to use the criminal law against a person who is generally motivated by the suffering of a relative, a friend, or a patient. In most cases prosecutors or grand juries refuse to indict, or juries find the person not guilty or temporarily insane. In 20 cases of active and passive euthanasia reported in two articles, only three involved sentences of imprisonment. ${ }^{67}$ These three cases, however, were unusual because they involved either a gruesome killing, ${ }^{68}$ a highly disputed motive, ${ }^{69}$ or disbelief that the victim was terminally ill or in pain. ${ }^{70}$ Glantz suggests that in practice, the chances of a conviction are remote if the defendant is related to or knows the person well, performs the act openly at personal risk, has reason to believe the person is suffering, and there is no self-serving motive. ${ }^{71}$ In such cases the defendants' compassionate intentions appear not only to lessen the offense or sentence, but actually to absolve them of criminal liability. Otto Werner, for example, suffocated his bedridden wife upon learning that they were being sent to a nursing home. The judge actually asked Mr. Werner to withdraw his guilty plea: "If testimony was brought out of his devotion and care for his wife, and her incurable illness and constant pain and suffering, the jury would not return a verdict of guilty."72

In a search of reported decisions, no case was found in which a health care professional was convicted of causing, inducing, or assisting in the death of her patient. In State v. Sander ${ }^{73}$ a physician noted in the medical record: "Patient was given $10 \mathrm{cc}$ of air intravenously repeated four times. Expired within ten minutes after this was started." He was acquitted. In three additional cases involving lethal injections of potassium chloride ${ }^{74}$ and morphine, ${ }^{75}$ health care professionals were acquitted. The defense in each case claimed that there was reasonable doubt that the patient may have died not from the injection but from the underlying disease. A Florida district attorney decided not to prosecute a physician who injected a patient with a dose of amytal sodium manufactured more than 30 years ago. The district attorney said a jury would not convict even though the doctor told the patient's wife that he would die shortly after the injection. The doctor's defense was that he was trying to ease pain rather than kill, even though he was aware of the patient's serious respiratory condition.

Dr. Jack Kevorkian has publicly claimed to have assisted the death of a number of patients. Despite several attempts by Michigan law enforcement authorities to prosecute and convict him, he has yet to be convicted. Dr. Kevorkian was charged with murder in connection with his first three assisted suicides, but the charges were dropped because Michigan had no law prohibiting assisted suicide. He was arrested after the enactment of an assisted suicide statute in Michigan but was not charged. ${ }^{76}$

The criminal law, then, appears virtually ineffective against health care professionals who can point either to the patients' underlying conditions or to their own intent 
to comfort patients as a defense against criminal liability. ${ }^{7}$

\section{Law reform on physician assisted dying}

Both sides in the physician assisted dying debate agree on the need for clearer public policy and law. ${ }^{78}$ At least some evidence exists that, despite the AMA's rejection of active euthanasia, ${ }^{79}$ ethical and public opinion has perceptibly shifted in favor of medical aid in dying. This shift is reflected in the public's attitude favoring physician assisted suicide; $;^{80}$ the refusal of prosecutors, grand juries and juries to indict or convict health care professionals; the growing number of respected physicians advocating medical aid in dying as the last act in a continuum of care provided to terminally ill patients; ${ }^{81}$ and an emerging argument by the legal profession that prohibitions of assisted suicides are unconstitutional. ${ }^{82}$

The law of assisted suicide serves no public purpose and is unfair to physicians if it fails to forewarn clearly about medical acts that are acceptable and those that will be criminally punished. Despite the consensus on the need for clearer public policy, few have come forward with reasoned proposals; the literature has stalled on the sterile question of whether euthanasia should belegalized. Rather, the question to be put is: what aspects of physician assisted suicide would provide most psychological comfort for the terminally ill without compromising key social values and the integrity of the medical profession? Here I propose an incremental adjustment in the line drawn by the law, together with safeguards necessary to ensure that the line holds relatively firm until the next development in ethical thought and public opinion.

Three levels of professional practice emerge in the euthanasia debate. ${ }^{83}$ The first level, abatement of life sustaining treatment (passive euthanasia) was considered unlawful until the gradual development of the patient's constitutional right to privacy and the enactment of natural death legislation beginning some two decades ago. The right of the incompetent, as well as the competent, patient to exercise this right to privacy is now well established.

It may be appropriate to consider a cautious approach into the second level of professional practicephysician assisted suicide. This term encompasses only the right of the physician, under narrow circumstances, to provide the medical knowledge and/or medical means to enable a competent patient to take his own life.

The law would still strictly prohibit all activities within the third level of professional practice-causing or inducing suicide (active euthanasia). Thus, it would continue to be a criminal offense for a physician to take direct and active means (physical or verbal) to cause or induce a patient's suicide such as by administering a fatal dose of morphine or potassium, placing an overdose of drugs in the patient's hands or mouth, or unduly influencing the patient.

Under this proposal, law and medical ethics would continue to maintain the moral distinction between letting die and killing. There remains almost universal agreement in law and medicine that letting die is ethical, while killing is not. No such agreement exists on physician assisted suicide. While both Dr. Kevorkian and Dr. Quill assisted in their patients' deaths, many observers reject Dr. Kevorkian's approach, but embrace Dr. Quill's. Why?

Physician assisted suicide should not be unlawful if the following conditions are met, most of which were present in Dr. Quill's report: (1) a long standing physician/patient relationship; (2) a clearly competent adult who has been well informed of all of the therapeutic and palliative alternatives, who has a firm and settled position, and who has provided a written consent; and (3) a confirmed prognosis of terminal illness indicating that the patient will die within six months. (The requirement that a terminal illness be present may eventually be found to be ethically unnecessary; however, such a requirement represents a cautious approach intended to minimize the likelihood of abuse.) To help ensure against abuse, the law could require at least two independent and dispassionate opinions that all of the conditions have been met-one by a medical specialist confirming the prognosis and one by a lay person witnessing the consent. Some states may require a more formal process conducted by an agency such as an ombudsman, office of elder affairs, or ethics committee. At least by some accounts, physician assistance in dying occurs with some frequency ${ }^{84}$ Establishing clear rules for the practice rather than benignly ignoring it will relieve physicians of the secrecy and isolation imposed by current criminal prohibitions. This will encourage full consultation with the patient's family and professional colleagues before medical assistance in dying is provided.

Justification for this proposed reform of the law includes greater autonomy and self-determination for patients, a concept widely affirmed in the legal and ethical literature. Physician assistance can enable patients to decide the manner and timing of their death. It is argued that euthanasia is not a matter of personal autonomy but a social issue. While it is true that patient autonomy does not always trump societal interests, taking one's life privately with medical advice does not trample the rights of others. Reforming the law of assisted suicide in accordance with specific criteria and procedures, moreover, represents a social, not a personal resolution of the ethical dilemma.

Medical advice and assistance at the end of life can also be comforting for terminally ill patients. It provides an assurance that when pain and psychological suffering 
become unbearable, patients can rely on their physicians to help them in achieving a peaceful and dignified death. The overwhelming majority of patients will never use the medical knowledge, but are comforted to know that they will not be abandoned if they need it. It is true that palliative care can substantially reduce the pain and discomfort of grave illness. The problem, however, is not simply pain but fear of debility, dependence, loss of cognition, and dehumanization from the underlying illness as well as the powerful effects of sedation.

Medically assisted suicide can also ensure privacy during the last days and weeks of life, allowing patients to die in a dignified manner in the place, and with the loved ones, of their choosing. Orentlicher ${ }^{85}$ and $\mathrm{Kass}^{86}$ both make a strong case that allowing medical assistance in dying would undermine the integrity of the profession and the trust of patients. Yet, a rule which permits, but does not require, a physician to discuss sensitively and openly all of the patient's concerns about dying would likely promote greater respect for the profession in a country where the public increasingly feels that medicine is failing the terminally ill. The physician should neither open the topic nor encourage suicide, but sympathetic conversation should reassure patients. ${ }^{87}$ Indeed, focusing policies about death and dying on the medical profession has distinct benefits since physicians are in the best position to provide sensitive and informed advice, and the profession is ethically accountable.

Whenever medical euthanasia is raised, any number of slippery slope arguments are put forward: What if physicians go beyond assisting to actual killing? Won't advocates claim the right for the incompetent as well as the competent? Will patients commit suicide to avoid burdening their families, emotionally and financially? Could patients be subject to undue influences from physicians and families? What if physicians helped teenagers or other depressed persons who would have had a change of heart? Will society's respect for human life diminish?

These are all serious questions. Many already arise in decisions to abate treatment or in decisions of patients to take their own lives with or without medical advice. No proposal to make death more comforting and dignified for patients can avoid the potential for abuse or the obvious inconsistencies in where society draws the line. Assisted suicide is not a panacea for achieving an open and sensitive discussion of death and a peaceful end of life. But it can be a small part of a continuum of medical treatment, palliative care, nurturing, and compassion that will allow dying patients to feel that they are not abandoned by the medical profession at a time when they need it most.

\section{References}

1. Cruzan v. Director, Missouri Department of Health,
110 S.Ct. 2841 (1990); Robert Weir, Lawrence O. Gostin, "Decisions to Abate Life-Sustaining Treatment for NonAutonomous Patients: Ethical Standards and Legal Liability for Physicians After Cruzan," JAMA, 264 (1990): 1846-1853.

2. Wrongful death statutes provide the primary civil remedy against a physician for assisted suicide. Since no case has addressed this issue, civil liability will not be discussed. $T$. Englehardt, Mallory, "Suicide and Assisting Suicide: A Critique of Legal Sanctions," S.W.L.J., 36 (1982): 1003.

3. Egan, "As Memory and Music Faded, Oregon Woman Chose Death," N.Y. Times, June 7, 1990, at 1, col. 1 .

4. "Death Machine' Barred by Circuit Court," Michigan Lawyers Weekly, February 11,1991, p.3; State exrel. Thompson v. Kevorkian, No. 90-390-AZ (Oakland County, Feb. 5, 1991).

5. E. Freedman, “'Dr. Death's' License Suspended by Medical Board," The Detroit News, Nov. 20, 1991.

6. Isabel Wilkerson, "Suicide Doctor Tests Law, Stays With Man Who Dies," N.Y. Times, May 17, 1993, A12.

7. Timothy E. Quill, "Death and Dignity-A Case of Individualized Decision Making," N.Eng.J.Med., 324 (1991): 691-694.

8. Anon, "It's Over, Debbie," JAMA, 259 (1988): 272; G. Lundberg, "It's Over Debbie' and the Euthanasia Debate," JAMA, 259 (1988): 2141-2.

9. Ronald Cranford, "Going Out in Style, the American Way, 1987," Law, Med. \& Health Care, 17 (1989): 208-210.

10. W.E. Schmidt, "Prosecutors Drop Criminal Case Against Doctor Involved in Suicide," N.Y. Times, Dec. 15, 1990, p. 10, col. 5; T. Lewin, "Doctor Cleared of Murdering Woman With Suicide Machine," N.Y. Times, December 14, 1990, p. B.6, col. 1.

11. L. Altman, "Jury Declines to Indict a Doctor Who Said He Aided in a Suicide," N.Y. Times, July 27, 1991, p. 1, col. 2.

12. J. Gross, "The 1991 Election: Euthanasia; Voters Turn Down Mercy Killing Idea," N.Y. Times, Nov. 7, 1991, B16, col. 1.

13. Bruce Hilton, "Politics and Medicine," Chicago Tribune, November 13, 1992 , p. 7.

14. P. Singer, M. Siegler, "Euthanasia-A Critique," $N$. Eng.J.Med., 322 (1990): 1881; De Wachter, "Active Euthanasia in the Netherlands," JAMA, 282 (1989): 3316.

15. R. Knox, "Poll: Americans Favor Mercy Killing," Boston Globe, November 3, 1991, p. 1.

16. Derek Humphry, Final Exit: The Practicalities of SelfDeliverance and Assisted Suicide for the Dying, (Seacaucus, NJ: Carol Publishing, 1991).

17. Cassel, Meier, "Morals and Moralism in the Debate Over Euthanasia and Assisted Suicide," NEJM, 323 (1990): 750; Cassel, et al.

18. In re Guardianship of Grant, 109 Wash 2d 545, 747 P.2d 445 (1987), modified 757 P.2d 534 (1988); Brophy v. New England Sinai Hospital, 398 Mass. 417, 497 N.E. 2d 626 (1986).

19. President's Commission for the Study of Ethical Problems in Medicine and Biomedical and Behavioral Research, Deciding to Forego Life Sustaining Treatment, Report on Ethical, Medical and Legal Issues in Treatment Decisions (March 1983); A. Meisel, The Right to Die, (New York: John Wiley, 1989; 1991 Crim. Supp. No. 2. 1991).

20. Lawrence O. Gostin, Robert Weir, "Life and Death Choices After Cruzan: Case Law and Standards of Professional Conduct," Milbank Quart., 69 (1991): 143-173.

21. Cruzan v. Director, Missouri Department of Health, 110 S. Ct. 2841 (1990).

22. Bouvia v. Superior Court, 179 Cal. App. 3d 1127, 225 
Cal. Rptr. 297 (1986).

23. Wons v. Public Health Trust, 541 So. $2 d 96$ (Fla. 1989); In re Fosmire, 75 N.Y. 218, 551 N.E. 2d 77 (1990).

24. Bouvia v. Superior Court, 179 Cal. App. $3 d 1127,225$ Cal. Rptr. 297 (1986).

25. In re Peter, 108 N.J. 365,529 A.2d 419 (1987).

26. In re Dinnerstein, 6 Mass. App. 466, 380 N.E. 2d 134 (Ct. App. 1978).

27. Rasmussen v. Flemming, 154 Ariz. 207, 741 P.2d 674 (1987).

28. In re Spring, 380 Mass. 629, 405 N.E. 2 d 115 (1980).

29. Estate of Leach v. Shapiro, 13 Ohio App.3d 393, 469 NE2d 1047 (1984); Strachan v. John F. Kennedy Memorial Hospital, 209 NJ Super. 300, 507 A.2d 718 (App. Div. 1986), affirmed in part, reversed in part, 109 N.J. 523,538 A.2d 346 (1988).

30. Barber v. Superior Court, 147 Cal. App. 3d 1006, 196 Cal. Rptr. 484 (1983).

31. In re Conroy, 98 N.J. 321,486 A.2d 1209 (1985); In re Colyer, 99 Wash.2d 114, 660 P.2d 738 (1983); Superintendent of Belchertown State School v. Saikewicz, 373 Mass. 728, 370 N.E. 2d 417 (1977). (1989).

32. In re Longway, 133 Ill. 2d 33, 549 N.E.2d 292, 298

33. In re Browning, 568 So.2d 4, 13 (Fla. 1990).

34. A. Meisel, The Right to Die, (New York: John Wiley, 1989, Crim. Supp. No 2, 1991).

35. R. v. Doody, 6 Cox Crim. Cas. 463 (1854); Hales v. Petit, 1 Plowd. 253, 75 Eng. Rep. 387 (C.B. 1565).

36. C.D. Shaffer, "Criminal Liability for Assisting Suicide," Colum. L. Rev., 86 (1986): 348-376.

37. 4 W. Blackstone, Commentaries 188-89; Hales v. Petit, 75 Eng. Rep. 387, 400 (KB 1565).

38. Blackburn v. State, 23 Ohio St. 146, 163 (1873); Cruzan v. Director, Missouri Department of Health, 110 S.Ct. 2841, 2859 , Scalia J. concurring.

39. G.P. Smith, "All's Well That Ends Well: Toward a Policy of Assisted Rational Suicide or Merely Enlightened SelfDetermination?" U.C. Davis L. Rev., 22 (1989): 275-419; State v. Willis, 255 N.C. 473, 121 S.E.2d 854 (1961).

40. Wallace v. State, 232 Ind. 700,116 N.E.2d 100 (1953).

41. State v. Cobb, 229 Kan. 522, 625 P.2d 1133 (1981);

State v. Fuller, 203 Neb. 233, 278 NW.2d 756 (1976).

42. Avon v. State, 102 Tex Crim. 478, 277 S.W. 1080 (1925).

43. Criminal homicide constitutes manslaughter when it is committed needlessly or under the influence of extreme mental or emotional disturbance. Model Penal Code, sec. 210.3.

44. People v. Matlock, 51 Cal. 2d 682, 336 P.2d 505 (1959); Goodin v. State, 726 S.W. 2d 956 (Tex. App. Fort Worth 1987).

45. State v. Bouse, 199 Or. 676, 264 P.2d 800 (1953), overruled on other grounds, State v. Fischer, 232 Or 558, 376 P.2d 418 (1962).

46. 229 Cal. App. 3d 367 (1991).

47. Model Penal Code, sec. 210.5 .

48. W.R. La Fave, A.W. Scott Jr., Criminal Law, (St. Paul, Minnesota: West Publishing Co. 2d ed 1980), sec. 7.8.

49. Y. Kamisar, "Some Non-Religious Views Against Proposed ‘Mercy Killing'Legislation,” Minn. L. Rev., 42 (1958): 969-1042.

50. State v. Fuller, 203 Neb. 233, 241, 278 N.W. 2d 756, 761 (1979).

51. State v. West, 157 Mo. 309, 57 S.W. 1071 (1900).

52. A. Meisel, The Right to Die, (New York: John Wiley,
1989), Cum. Supp. No. 2, 1991 (AK, AZ, AR, CA, CO, CT, DE, FL, KS, ME, MN, MS, MO, NE, NH, NJ, NM, NY, OK, OR, PA, SC, SD, TX, WA, WI); Recently, a bill was passed by the Georgia House on prohibiting assisted suicide. The bill was not enacted as of June 1993. "93 Georgia Legislature," Atlanta Constitution, February 26, 1993, Sec. E at 3; G.P. Smith, "All's Well That Ends Well: Toward a Policy of Assisted Rational Suicide or Merely Enlightened Self-Determination?" U.C. Davis L. Rev., 22 (1989): 275-419; G.C. Garbesi, "The Law of Assisted Suicide," Issues in Law or Med., 3 (1987): 93-111.

53. "Kevorkian Arrested in Suicide; Retired Doctor May Face Trial Under New Michigan Law," Chicago Tribune, May 17, 1993, p. 3; Isabel Wilkerson, "Suicide Doctor Tests Law, Stays With Man Who Dies," N.Y. Times, May 17, 1993, A12. 54. Steve Marshall, "Michigan Challenges Suicide Law Reversal," USA Today, June 3, 1993, 3A.

55. HI, $\mathbb{N}$.

56. Note, "Criminal Liability of Participants in Suicide: State v. Williams," Md. L. Rev., 5 (1941): 324; Commonwealth v. Dennis, 105 Mass. 162 (1870).

57. Chanslo v. State, 697 S.W.2d 393 (Tex. Crim. App. 1985).

58. Burnett v. People, 204 Ill. 208, 68 N.E. 505 (1903); Blackburn v. State, 23 Ohio St. 146 (1870); People v. Roberts, 211 Mich. 187, 178 N.W. 690 (1920), overruled in People v. Campbell, 335 N.W. 2d 27 (Mich. App. 1983).

59. People v. Roberts, 211 Mich. 187,178 N.W. 690 (1920), overruled in People v. Campbell, 335 N.W. 2d 27 (Mich. App. 1983).

60. State v. Bier, 181 Mont. 27, 591 P.2d 1115 (1979).

61. Persampieriv. Commonwealth, 343 Mass. 19, 175 N.E. 2d 387 (1961).

62. State v. Marti, 290 NW 2d 570 (Iowa 1980).

63. People v. Campbell, 335 N.W.2d 27 (Mich App. 1983);

Avon v. State, 102 Tex. Crim. 478, 277 S.W. 1080 (1925).

64. Attorney General v. Able [1984] All ER. 277.

65. R. v. Nicholas Reed [1982] Crim. App. 819.

66. McCollum v. CBS, Inc., 202 Cal. App. 3d 989, 249 Cal. Rptr. 187 (2nd Dist. 1988).

67. "Survey, Euthanasia: Criminal, Tort, Constitutional and Legislative Considerations," Notre Dame Lawyer, 48 (1973): 1202; Leonard H. Glantz, "Withholding and Withdrawing Treatment: The Role of the Criminal Law," Law, Med. \& Health Care, 15 (1987): 231-241.

68. N.Y. Times, Sept. 28, 1943, at 27, col. 2, Uohn Noxon convicted of murder for electrocuting his son who had Down's Syndrome).

69. N.Y. Times, April 4, 1950, at 60, col. 4. (Harold Mohr convicted or voluntary manslaughter for killing his cancer ridden brother while he was drinking).

70. (Roswell Gilbert shot his wife who was suffering from Alzheimer's disease and was sentenced to life imprisonment).

71. Leonard Glantz, "Withholding and Withdrawing Treatment: The Role of the Criminal Law," Law, Med. \& Health Care, 15 (1987): 231-241.

72. A. Morris, "Voluntary Euthanasia," Washington Law Review 45 (1969), 239.

73. N.Y. Times, Feb. 24, 1950, at 1, col. 6.

74. N.Y. Times, Jan. 13, 1974, at 44. (Dr. Vincent Montemarano acquitted of killing a cancer patient with an injection of potassium chloride who died within five minutes).

75. Derek Humphry, ed. "Assisted Suicide: The Compassionate Crime," (Hemlock Society, 1984), p. 16. (Nurse Anne Capute acquitted of murdering a cancer patient with an injection of $195 \mathrm{mgs}$ of morphine within seven hours of her 
death); M. Green, M. Grant, "A Florida Jury Finds No Guilt in Physician Peter Rosier's Trial," Time Magazine, Dec. 19, 1988.

76. "Kevorkian Arrested in Suicide; Retired Doctor May Face Trial Under New Michigan Law," Chicago Tribune, May 17, 1993, p. 3.

77. J. Rae-Dupree, "Wife, Doctor Won't Be Charged in Death," LA Times, Nov. 6, 1991, B10, col. 4.

78. E.D. Pellegrino, "Ethics," JAMA, 265 (1991): 31183119.

79. "Current Opinions of the Council on Ethical and Judicial Affairs of the AMA-1989: Withholding or Withdrawing LifeProlonging Treatment," (Chicago, Ill: AMA, 1989).

80. "Boston Globe/Harvard Poll, OnU.S. Attitudes Toward Death and Dying," Conducted by KRC Communications Research, Oct 18-20, 1991 (national sample of 1,311 adults over age 18).

81. S.H. Wanzer, D.D. Federman, S.J. Adelstein, et al, "The Physician's Responsibility Toward Hopelessly Ill Patients," $N$. Engl.J. Med., 320 (1989): 844-849; M. Angell, “Don't Criticize
Doctor Death," N.Y. Times, June 14, 1990, A 27, col. 1; Timothy E. Quill, Christine K. Cassel, Diane E. Meier, "Care of the Hopelessly Ill; Proposed Clinical Criteria for Physician Assisted Suicide," N. Engl. J. Med., 327 (1992): 1380-1384.

82. Note, "Physician-Assisted Suicide and the Right to Die With Assistance," Harv. L. Rev., 105 (1992): 2021; Yale Kamisar, "Are Laws Against Assisted Suicide Unconstitutional?" Hastings Center Report, 23 (May-June 1993): 32-41.

83. G.D. Lundberg, "'It's Over, Debbie' and the Euthanasia Debate,"JAMA, 259 (1988): 2142-2143.

84. S.H. Wazner, D.D. Federman, S.J. Adelstein, et al, "The Physician's Responsibility Toward Hopelessly Ill Patients," $N$. Eng. J. Med., 320 (1989): 844-849.

85. D. Orentlicher, "Physician Participation in Assisted Suicide," JAMA, 262 (1989): 1844-1845.

86. L.R. Kass, "Neither for Love or Money: Why Doctors Must Not Kill," Public Interest, 94 (1989): 25-46.

87. K. Kipnos, "Physician Participation in Assisted Suicide (letter)," JAMA, 263 (1990): 1197-1198. 